\title{
Persepsi Manfaat, Kemudahan Penggunaan dan Minat Menggunakan Internet Banking dengan Sikap Sebagai Variabel Intervening
}

\author{
Ni Putu Mahesa Arsita Putri ${ }^{1}$ \\ Fakultas Ekonomi dan Bisnis \\ Universitas Udayana, Indonesia
}

\author{
I Gusti Ngurah Agung Suaryana ${ }^{2}$ \\ Fakultas Ekonomi dan Bisnis \\ Universitas Udayana, Indonesia
}

Surel : infoarsitaputri@yahoo.com

\section{ABSTRAK}

Penelitian ini bertujuan untuk mengetahui pengaruh persepsi manfaat dan kemudahaan penggunaan terhadap minat dalam menggunakan internet banking BRI dengan peran sikap sebagai variabel intervening. Teknik analisis yang digunakan adalah Struktural Equation Modeling (SEM) dengan pendekatan variance based atau component based dengan Partial Least Square (PLS). Hasil penelitian ini menunjukkan bahwa, Persepsi manfaat berpengaruh positif dan signifikan terhadap sikap, Kemudahan penggunaan berpengaruh positif dan signifikan terhadap sikap, Persepsi manfaat berpengaruh positif dan signifikan terhadap minat, Kemudahan penggunaan berpengaruh positif dan signifikan terhadap minat, Sikap berpengaruh positif dan signifikan terhadap minat, Persepsi manfaat berpengaruh positif dan signifikan terhadap minat melalui sikap sebagai avriabel intervening, Kemudahan penggunaan berpengaruh positif dan signifikan terhadap minat melalui sikap sebagai variabel intervening.

Kata Kunci: Persepsi Manfaat; Kemudahan Penggunaan; Sikap; Minat.

Perception of Benefits, Ease of Use and Interest in Using Internet Banking with Attitude as an Intervening Variable

\section{ABSTRACT}

This study aims to determine the effect of perceived usefulness and ease of use on interest in using BRI internet banking with the role of attitude as an intervening variable. The analysis technique used is Structural Equation Modeling (SEM) with a variance based or component based approach with Partial Least Square (PLS). The results of this study indicate that, Perception of benefits has a positive and significant effect on attitudes, Ease of use has a positive and significant effect on attitudes, Perception of benefits has a positive and significant effect on interests, Ease of use has a positive and significant effect on interests, Attitude has positive and significant effect on interest, Perception of benefits has positive and significant effect on interest through attitude as avriable intervening, Ease of use has positive and significant effect on interest through attitude as attitude as intervening variable.

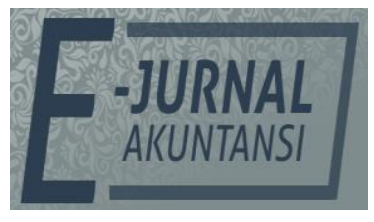

e-ISSN 2302-8556

Vol. 31 No. 6

Denpasar, Juni 2021

Hal. 1375-1389

DOI:

10.24843/EJA.2021.v31.i06.p02

PENGUTIPAN:

Putri, N.P.M.A., \& Suaryana, I G.N.A. (2021). Persepsi Manfaat, Kemudahan Penggunaan dan Minat Menggunakan Internet Banking dengan Sikap Sebagai Variabel Intervening. E-Jurnal Akuntansi, 31(6), $1375-1389$

RIWAYAT ARTIKEL: Artikel Masuk: 12 November 2019 Artikel Diterima: 19 Juni 2021

Keywords: Perception of Benefits; Ease of Use; Attitude; Interest.

Artikel dapat diakses : https://ojs.unud.ac.id/index.php/Akuntansi/index 


\section{PENDAHULUAN}

Teknologi infomasi secara bertahap telah mengubah realitas menjadi dunia maya. Salah satu bagian teknologi yaitu internet telah mendorong pertumbuhan konsep internet banking. Internet banking pertama kali muncul di Amerika Serikat pada pertengahan tahun 1990-an, dimana lembaga keuangan di Amerika Serikat memperkenalkan dan mempromosikan internet banking untuk menyediakan layanan perbankan yang lebih baik (Sri Maharsi, 2017). Internet banking adalah salah satu pelayanan jasa bank yang memungkinkan nasabah untuk memperoleh informasi, melakukan komunikasi dan melakukan transaksi perbankan melalui jaringan internet, dan bukan merupakan bank saja yang hanya menyelenggarakan layanan perbankan melalui internet (Tampubolon, 2014). Layanan internet banking memberikan manfaat untuk nasabah dan bank.

Persepsi manfaat akan diketahui ketika pengguna telah menggunakan internet banking yang mencerminkan timbal balik antara pengguna tidak menggunakan dan setelah pengguna menggunakan. Pekerjaan yang dilakukan dirasa lebih efisien menggunakan internet banking daripada tidak menggunakan maka tanpa sadar dalam diri pengguna akan timbul keinginan atau minat untuk ingin kembali menggunakan internet banking tersebut. Adapun fenomena yang terjadi di PT Bank Rakyat Indonesia Cabang Denpasar Renon mengenai persepsi manfaat internet banking adalah dimana sistem belum mampu meningkatkan kinerja individu, sistem belum mampu menambah tingkat produktifitas dan sistem belum mampu meningkatkan efektifitas kinerja.

Kemudahan penggunaan internet banking yang disediakan oleh bank dilakukan melalui situs bank, yang dapat diakses oleh nasabah setiap saat tanpa harus datang ke bank. Fitur-fitur yang disediakan dalam situs bank tersebut antara lain yaitu cek saldo, mutasi rekening sampai transfer, melakukan pembayaran tagihan, kliring, pembukaan dan penutupan rekening, dan lain-lain dapat dilakukan asalkan memiliki koneksi ke internet. Kemudahan lainnya ialah karena situs itu sama seperti situs-situs lain pada umumnya, sehingga nasabah dapat secara langsung mengakses layanan internet banking (Marieta, 2014). Selain itu internet banking juga dapat memudahkan nasabah dalam hal memperoleh informasi, berita dan analisis seputar foreign exchange transaction. Baru-baru ini internet banking juga memberikan pelayanan diluar produk perbankan seperti pembelian voucher isi ulang dan langsung dapat mendebet rekening nasabah, pembayaran polis atau dapat melakukan pembelian saham secara online. Adapun fenomena yang terjadi di PT Bank Rakyat Indonesia Cabang Denpasar Renon mengenai kemudahaan penggunaan internet banking adalah dimana interaksi antara individu dan sistem kurang jelas dan tidak mudah dimengerti, terlalu banyak usaha untuk berinteraksi dengan sistem tersebut dan sistem terlalu sulit digunakan.

Sikap pemakaian internet banking yang secara terus-menerus dan berkala dapat menumbuhkan hubungan jangka panjang antara nasabah dengan pihak bank. Oleh sebab itu untuk mempertahankan hubungan jangka panjang dengan nasabahnya, bank harus selalu berkomunikasi dengan nasabahnya. Sehingga nasabah merasa aman dan percaya terhadap bank tersebut, karena nasabah dapat dengan mudah memperoleh informasi yang mereka inginkan dari bank tersebut (Mukherjee \& Nath, 2013). Konsumen yang tidak mendapatkan informasi yang 
lengkap tentang kualitas suatu produk, seringkali kehilangan kepercayaan untuk melakukan transaksi online. Banyak kasus tindak kejahatan dalam menggunakan internet banking di Indonesia, salah satunya yang paling populer adalah kasus pembobolan rekening nasabah. Dengan timbulnya beberapa kasus kecurangan menggunakan media internet banking, dan tidak adanya interaksi fisik antara pegawai bank dengan nasabah akan menyebabkan nasabah tidak percaya terhadap internet banking. Ketidakpercayaan nasabah terhadap internet banking dapat menimbulkan rasa takut pada nasabah untuk menggunakan internet banking.

PT Bank Rakyat Indonesia merupakan salah satu perusahaan BUMN dan penyedia jasa keuangan yang ada di seluruh Indonesia salah satunya pulau Bali. Bank sebagai lembaga yang bergerak dalam bidang jasa keuangan sudah seharusnya meningkatkan pertumbuhan pengguna internet banking, Keberhasilan internet banking tergantung dari bagaimana nasabah menerima sistem tersebut. Oleh karena itu, penting bagi pihak bank untuk mengetahui bagaimana para konsumennya mengapresiasi jasa internet banking agar dapat membantu menemukan rencana strategis dan meningkatkan pangsa pasar. Dengan demikian, isu penting bagi pihak bank ketika menerapkan internet banking adalah, untuk mengetahui faktor-faktor apa saja yang mempengaruhi keputusan para nasabah menggunakan jasa pelayanan internet banking. Adapun data pengguna internet banking pada Bank Rakyat Indonesia Kantor Cabang SeBali meliputi 13 cabang yang terdiri dari kantor cabang Amlapura, kantor cabang Bangli, kantor cabang Denpasar Gajah Mada, kantor cabang Gianyar, kantor cabang Kuta, kantor cabang Denpasar Gatot Subroto, kantor cabang Denpasar Ubud, kantor cabang Tabanan Kediri, kantor cabang Negara, kantor cabang Denpasar Renon, kantor cabang Semarapura, kantor cabang Singaraja dan kantor cabang Tabanan.

Beberapa penelitian yang mengkaitkan antara persepsi manfaat terhadap minat penggunaan menurut Priambodo \& Prabawani (2015) mengatakan bahwa bila layanan uang elektronik memberikan berbagai manfaat bagi penggunanya, maka pengguna dengan senang hati akan menggunakan layanan uang elektronik. Hal tersebut nantinya secara langsung akan mempengaruhi minat menggunakan layanan uang elektronik. Sebaliknya bila pengguna beranggapan bahwa uang elektronik tidak memberikan manfaat sama sekali pada dirinya, maka pengguna tidak akan berminat lagi untuk menggunakannya karena terdapat berbagai macam pilihan alat transaksi non-tunai lainnya. Namun Ricmala (2016) menyatakan bahwa kemungkinan tidak adanya manfaat yang optimal yang akan diperoleh nasabah setelah menggunakan layanan mobile banking tersebut. Dan bisa saja dikarenakan faktor pemakaian pulsa dalam transaksi mobile banking yang menyebabkan nasabah juga kurang berniat dalam menggunakan layanan mobile banking.

Persepsi manfaat berperan penting dalam mempengaruhi sikap, bahwa dapat diketahui bila layanan uang elektronik memberikan berbagai manfaat bagi penggunanya, maka pengguna dengan senang hati akan menggunakan layanan uang elektronik. Hal tersebut nantinya secara langsung akan mempengaruhi sikap dalam menggunakan layanan uang elektronik (Istiarni, 2014). 
Sikap pemakaian internet banking yang secara terus-menerus dan berkala dapat menumbuhkan hubungan jangka panjang antara nasabah dengan pihak bank. Oleh sebab itu untuk mempertahankan hubungan jangka panjang dengan nasabahnya, bank harus selalu berkomunikasi dengan nasabahnya agar sikap nasbaah menjadi semakin meningkat (Novita \& Giantari, 2016). Berdasarkan dengan analisis tersebut maka pengembangan hipotesis dalam penelitian ini dapat dirumuskan sebagai berikut:

H1: Persepsi manfaat berpengaruh positif pada sikap.

Kemudahan penggunaan dapat menimbulkan sikap yang positif dimana layanan kemudahan kegunaan internet banking memberikan berbagai manfaat bagi penggunanya, maka pengguna dengan senang hati akan menggunakan layanan tersebut (Andriyanto, 2016).

Pascaningrum Risdwiyanto (2013) menyatakan bahwa sikap konsumen terhadap belanja online tergantung dari fitur-fitur yang relevan yang terdapat dalam belanja online. Fitur belanja online dapat berupa persepsi fungsional konsumen dan dimensi utilitarian, seperti kemudahan penggunaan dan kegunaan atau persepsi emosional konsumen. Berdasarkan dengan analisis tersebut maka pengembangan hipotesis dalam penelitian ini dapat dirumuskan sebagai berikut. $\mathrm{H} 2$ : Kemudahan penggunaan berpengaruh positif pada sikap.

Minat konsumen dalam menggunakan internet banking kemungkinan adanya manfaat yang optimal yang akan diperoleh nasabah setelah menggunakan layanan internet banking tersebut, dan bisa saja dikarenakan faktor keamanan transaksi internet banking yang menyebabkan nasabah menjadi berniat dalam menggunakan layanan internet banking (Ricmala, 2016).

Sanjaya (2015) menyatakan persepsi manfaat mempunyai hubungan erat terhadap minat, dimana semakin baik persepsi manfaat yang dirasakan mahasiswa maka mampu meningkatkan minat mahasiswa didalam menggunkan internet banking. Berdasarkan dengan analisis tersebut maka pengembangan hipotesis dalam penelitian ini dapat dirumuskan sebagai berikut.

H3: Persepsi manfaat berpengaruh positif pada minat.

Kemudahan penggunaan dapat menimbulkan minat yang positif dimana penggunaan internet banking yang disediakan oleh bank dilakukan melalui situs bank, yang dapat diakses oleh nasabah setiap saat tanpa harus datang ke bank. Kemudahan lainnya ialah karena situs itu sama seperti situs-situs lain pada umumnya, sehingga nasabah dapat secara langsung mengakses layanan internet banking (Marieta, 2014).

Menurut penelitian yang dilakukan (Nurrahmanto, 2015) menunjukkan bahwa kemudahan penggunaan menjadi pertimbangan ssebelum melakukan belanja online. Faktor penggunaan ini berkaitan dengan bagaimana operasional belanja online. Meskipun belanja online memiliki banyak manfaat, namun kerumitan dalam berinteraksi dengan medianya dalam hal ini adalah situs jual beli online. Jika situs lebih mudah digunakan dan memberikan manfaat kepada calon pembeli makan calon pembeli ajan menggunakan situs tersebut untuk belanja online. Berdasarkan dengan analisis tersebut maka pengembangan hipotesis dalam penelitian ini dapat dirumuskan sebagai berikut.

H4: Kemudahan penggunaan berpengaruh positif pada minat. 
Sikap pemakaian internet banking yang secara terus-menerus dan berkala dapat menumbuhkan hubungan jangka panjang antara nasabah dengan pihak bank. Oleh sebab itu untuk mempertahankan hubungan jangka panjang dengan nasabahnya, bank harus selalu berkomunikasi dengan nasabahnya agar sikap nasbaah menjadi semakin meningkat Novita \& Giantari (2016).

Minat konsumen dalam menggunakan internet banking kemungkinan adanya manfaat yang optimal yang akan diperoleh nasabah setelah menggunakan layanan internet banking tersebut, dan bisa saja dikarenakan faktor keamanan transaksi internet banking yang menyebabkan nasabah menjadi berniat dalam menggunakan layanan internet banking Ricmala (2016). Berdasarkan dengan analisis tersebut maka pengembangan hipotesis dalam penelitian ini dapat dirumuskan sebagai berikut.

H5: sikap berpengaruh positif pada minat.

Sikap dalam hal ini akan mempengaruhi minat konsumen dilihat dari perilaku yang khusus dalam memanfaatkan teknologi informasi yang ditunjukkan dengan intensi perilaku (Stiari, 2014).

Prabawalingga \& Yadnyana (2016) mengatakan bahwa adanya suatu korelasi nyata secara statistik antara persepsi kemanfaatan terhadap perilaku, persepsi kemanfaatan dan penggunaan. Apabila seseorang merasa percaya bahwa sistem informasi berguna, maka dia akan menggunakan sistem informasi tersebut, jadi minat nasabah akan meningkat jika sikap nasabah positif dalam menggunakan internet banking. Berdasarkan dengan analisis tersebut maka pengembangan hipotesis dalam penelitian ini dapat dirumuskan sebagai berikut. H6: Persepsi manfaat berpengaruh positif pada minat melalui sikap sebagai variabel intervening.

Persepsi tentang kemudahan penggunaan sebuah teknologi sebagai suatu ukuran dimana seseorang percaya bahwa, komputer dapat dengan mudah dipahami dan digunakan. Jika seseorang merasa percaya bahwa sistem tersebut berguna maka dia akan bereaksi positif terhadap sistem tersebut dan akan menggunakannya Chau \& Lai (2013).

Hasil penelitian Feronica Mayasari et al. (2013) menunjukkan bahwa nasabah yang telah merasa nyaman, percaya, mampu dan merasa puas terhadap layanan internet banking akan terus menggunakan layanan ini untuk mendukung kegiatan mereka sehari-hari. Layanan internet banking yang baik dan canggih juga akan memberikan dampak positif terhadap bank, yaitu dengan timbulnya citra baik dari nasabah untuk bank. Sehingga mereka akan berbondong-bondong memilih bank tersebut untuk mempercayakan segala hal menyangkut keuangannya. Berdasarkan dengan analisis tersebut maka pengembangan hipotesis dalam penelitian ini dapat dirumuskan sebagai berikut.

H7: Kemudahan penggunaan berpengaruh positif pada minat melalui sikap sebagai variabel intervening.

\section{METODE PENELITIAN}

Penelitian ini dilakukan pada perusahaan perbankan di PT Bank Rakyat Indonesia Cabang Denpasar Renon yang beralamat di jalan Dr Kusuma Atmaja No 1 Denpasar Renon. Latar belakang pemilihan lokasi penelitian di tempat ini adalah ditemukannya masalah di PT Bank Rakyat Indonesia Cabang Denpasar 
Renon yang berkaitan dengan persepsi manfaat, kemudahan penggunaan, sikap dan minat.

Populasi dalam penelitian ini adalah nasabah pengguna internet banking di PT Bank Rakyat Indonesia Cabang Denpasar Renon berjumlah 16.624. Adapun jumlah sampel minimum yang ditentukan dalam penelitian ini menggunakan rumus Slovin, yaitu.

$\mathrm{n}=\frac{16.624}{1+16.624(0,1)^{2}}=97,9$

$\mathrm{n}=97,9$ dibulatkan menjadi 98

Berdasarkan kalkulasi dengan rumus Slovin di atas, maka jumlah sampel minimum yang ditargetkan dalam penelitian adalah sebanyak 98 orang Adapun metode pengambilan sampel (sampling) dalam penelitian ini adalah proportionate sampling atau pengambilan sampel secara proporsional dengan kriteria nasabah yang menggunakan internet banking pada PT Bank Rakyat Indonesia dan memiliki usia minimal 18 tahun keatas. Sedangkan penentuan responden menggunakan random sampling (sampling acak) dengan undian pada daftar nasabah.

Metode analisis inferensial digunakan dalam penelitian ini menggunakan Smart PLS adalah untuk menguji model pengukuran dan model struktural secara sekaligus dengan data analisis yang tersedia sebanyak 100 dari distribusi kuesioner.

\section{HASIL DAN PEMBAHASAN}

Hasil uji validasi koefisien path pada setiap jalur untuk pengaruh langsung dan efek dapat disajikan pada Tabel 1, berikut ini.

Tabel 1. Hasil Pengujian Efek Langsung

\begin{tabular}{llll}
\hline No & Hubungan antar Variabel & $\begin{array}{l}\text { Koefisien Jalur } \\
\text { (Bootstrapping) }\end{array}$ & T-Statistic \\
\hline 1 & Persepsi Manfaat $\left(\mathrm{X}_{1}\right) \rightarrow$ Sikap $\left(\mathrm{Y}_{1}\right)$ & 0,658 & 9,503 \\
2 & Kemudahan Penggunaan $\left(\mathrm{X}_{2}\right) \rightarrow$ Sikap $\left(\mathrm{Y}_{1}\right)$ & 0,268 & 3,100 \\
3 & Persepsi Manfaat $\left(\mathrm{X}_{1}\right) \rightarrow$ Minat $\left(\mathrm{Y}_{2}\right)$ & 0,759 & 20,562 \\
4 & Kemudahan Penggunaan $\left(\mathrm{X}_{2}\right) \rightarrow$ Minat $\left(\mathrm{Y}_{2}\right)$ & 0,231 & 6,242 \\
5 & Sikap $\left(\mathrm{Y}_{1}\right) \rightarrow$ Minat $\left(\mathrm{Y}_{2}\right)$ & 0,043 & 2,968 \\
\hline
\end{tabular}

Sumber: Data Penelitian, 2019

Persepsi manfaat $\left(X_{1}\right)$ berpengaruh positif dan signifikan terhadap sikap $\left(\mathrm{Y}_{1}\right)$. Hasil ini ditunjukkan oleh koefisien jalur yang bernilai positif sebesar 0,658 dengan $t$-statistic 9,503 (t-statistic $>1,96$ ), yang berarti bahwa hipotesis diterima dan secara empiris. Hasil yang diperoleh dapat dimaknai semakin bermanfaatnya internet banking bagi pengguna maka akan berdampak pada meningkatnya sikap pengguna terhadap internet banking PT Bank Rakyat Indonesia Cabang Denpasar Renon.

Kemudahan penggunaan $\left(\mathrm{X}_{2}\right)$ berpengaruh positif dan signifikan terhadap sikap $\left(\mathrm{Y}_{1}\right)$. Hasil ini ditunjukkan oleh koefisien jalur yang bernilai positif sebesar 0,268 dengan $t$-statistic 3,100 (t-statistic > 1,96), yang berarti bahwa hipotesis diterima dan secara empiris. Hasil yang diperoleh dapat dimaknai semakin mudahnya cara menggunakan internet banking maka akan berdampak pada 
meningkatnya sikap pengguna terhadap internet banking PT Bank Rakyat Indonesia Cabang Denpasar Renon.

Persepsi manfaat $\left(\mathrm{X}_{1}\right)$ berpengaruh positif dan signifikan terhadap minat $\left(\mathrm{Y}_{2}\right)$. Hasil ini ditunjukkan oleh koefisien jalur yang bernilai positif sebesar 0,759 dengan $t$-statistic 20,562 ( $t$-statistic $>1,96$ ), yang berarti bahwa hipotesis diterima dan secara empiris. Hasil yang diperoleh dapat dimaknai semakin bermanfaatnya internet banking bagi pengguna maka akan berdampak pada meningkatnya minat pengguna terhadap internet banking PT Bank Rakyat Indonesia Cabang Denpasar Renon.

Kemudahan penggunaan $\left(\mathrm{X}_{2}\right)$ berpengaruh positif dan signifikan terhadap minat $\left(\mathrm{Y}_{2}\right)$. Hasil ini ditunjukkan oleh koefisien jalur yang bernilai positif sebesar 0,231 dengan $t$-statistic 6,242 (t-statistic > 1,96), yang berarti bahwa hipotesis diterima dan secara empiris. Hasil yang diperoleh dapat dimaknai semakin mudahnya cara menggunakan internet banking maka akan berdampak pada meningkatnya minat pengguna terhadap internet banking PT Bank Rakyat Indonesia Cabang Denpasar Renon.

Sikap $\left(Y_{1}\right)$ berpengaruh positif dan signifikan terhadap minat $\left(\mathrm{Y}_{2}\right)$. Hasil ini ditunjukkan oleh koefisien jalur yang bernilai positif sebesar 0,043 dengan $t$ statistic 2,968 (t-statistic > 1.96), yang berarti bahwa hipotesis diterima dan secara empiris. Hasil yang diperoleh dapat dimaknai semakin positif sikap responden dalam menggunakan internet banking maka akan berdampak pada meningkatnya minat pengguna terhadap internet banking PT Bank Rakyat Indonesia Cabang Denpasar Renon.

Dalam pengujian hipotesis berikut ini akan dikaji peran mediasi variabel sikap $\left(\mathrm{Y}_{1}\right)$. Adapun pengujian hipotesis pengaruh tak langsung dalam penelitian ini dapat dipaparkan hasil analisisnya dalam Tabel 2.

Tabel 2. Rekapitulasi Hasil Pengujian Variabel Mediasi

\begin{tabular}{|c|c|c|c|c|c|c|}
\hline No & $\begin{array}{l}\text { Mediasi } \\
\text { Variabel } \\
\text { Sikap }\left(Y_{1}\right)\end{array}$ & $\begin{array}{l}\text { Efek } \\
\text { (A) }\end{array}$ & (B) & (C) & (D) & Keterangan \\
\hline 1 & $\begin{array}{l}\text { Persepsi } \\
\text { Manfaat }\left(\mathrm{X}_{1}\right) \\
\rightarrow \text { Minat }\left(\mathrm{Y}_{2}\right) \\
\text { Kemudahan }\end{array}$ & $\begin{array}{l}0,658 \\
\text { (Sig.) }\end{array}$ & $\begin{array}{l}0,744 \\
\text { (Sig.) }\end{array}$ & $\begin{array}{l}0,759 \\
\text { (Sig.) }\end{array}$ & $\begin{array}{l}0,043 \\
\text { (Sig.) }\end{array}$ & $\begin{array}{l}\text { Partial } \\
\text { Mediation }\end{array}$ \\
\hline 2 & $\begin{array}{l}\text { Penggunaan } \\
\left(X_{1}\right) \rightarrow \text { Minat } \\
\left(Y_{2}\right)\end{array}$ & $\begin{array}{l}0,268 \\
\text { (Sig.) }\end{array}$ & $\begin{array}{l}0,290 \\
\text { (Sig.) }\end{array}$ & $\begin{array}{l}0,231 \\
\text { (Sig.) }\end{array}$ & $\begin{array}{l}0,043 \\
\text { (Sig.) }\end{array}$ & $\begin{array}{l}\text { Partial } \\
\text { Mediation }\end{array}$ \\
\hline
\end{tabular}

Sumber: Data Penelitian, 2018

Berdasarkan hasil tersebut maka dapat dinyatakan bahwa semakin bermanfaatnya internet banking bagi pengguna akan berdampak pada meningkatnya sikap pengguna dan secara langsung akan berdampak meningkatnya minat pengguna terhadap internet banking. Selain itu efek mediasi variabel sikap $\left(\mathrm{Y}_{1}\right)$ pada pengaruh tak langsung persepsi manfaat $\left(\mathrm{X}_{1}\right)$ terhadap minat $\left(\mathrm{Y}_{2}\right)$ bersifat parsial (partial mediation). Hal ini berarti bahwa, variabel sikap $\left(\mathrm{Y}_{1}\right)$ adalah bukan sebagai variabel penentu kunci karena tanpa adanya variabel mediasi sikap $\left(\mathrm{Y}_{1}\right)$, variabel persepsi manfaat $\left(\mathrm{X}_{1}\right)$ sudah berpengaruh signifikan terhadap minat $\left(\mathrm{Y}_{2}\right)$. 
Berdasarkan hasil tersebut maka dapat dinyatakan bahwa semakin mudah cara menggunakan internet banking akan berdampak pada meningkatnya sikap pengguna dan secara langsung akan berdampak meningkatnya minat pengguna terhadap internet banking. Selain itu efek mediasi variabel sikap $\left(\mathrm{Y}_{1}\right)$ pada pengaruh tak langsung kemudahan penggunaan $\left(\mathrm{X}_{2}\right)$ terhadap minat $\left(\mathrm{Y}_{2}\right)$ bersifat parsial (partial mediation). Hal ini berarti bahwa, variabel sikap $\left(\mathrm{Y}_{1}\right)$ adalah bukan sebagai variabel penentu kunci karena tanpa adanya variabel mediasi sikap $\left(\mathrm{Y}_{1}\right)$, variabel kemudahan penggunaan $\left(\mathrm{X}_{2}\right)$ sudah berpengaruh signifikan terhadap minat $\left(\mathrm{Y}_{2}\right)$.

Tabel 3. Kalkulasi Efek Langsung, Tak Langsung dan Total

\begin{tabular}{|c|c|c|c|c|}
\hline No & Hubungan Variabel & $\begin{array}{l}\text { Efek } \\
\text { Langsung }\end{array}$ & $\begin{array}{ll}\text { Efek Tak } \\
\text { Langsung }\end{array}$ & Efek Total \\
\hline 1 & $\begin{array}{l}\text { Persepsi Manfaat }\left(\mathrm{X}_{1}\right) \\
\rightarrow \text { Sikap }\left(\mathrm{Y}_{1}\right) \\
\text { Kemudahan }\end{array}$ & $0,658^{\mathrm{s}}$ & - & 0,658 \\
\hline 2 & $\begin{array}{lll}\text { Penggunaan } & \left(X_{2}\right) \quad \rightarrow \\
\text { Sikap }\left(Y_{1}\right) & & \end{array}$ & $0,268 \mathrm{~s}$ & - & 0,268 \\
\hline 3 & $\begin{array}{l}\text { Persepsi Manfaat }\left(X_{1}\right) \\
\rightarrow \text { Minat }\left(Y_{2}\right)\end{array}$ & $0,759 \mathrm{~s}$ & $\begin{array}{l}0,759^{*} 0,744 \\
(0,564)\end{array}$ & 1,323 \\
\hline 4 & $\begin{array}{l}\text { Kemudahan } \\
\text { Penggunaan } \quad\left(X_{2}\right) \quad \rightarrow \\
\text { Minat }\left(Y_{2}\right)\end{array}$ & $0,231^{\mathrm{s}}$ & $\begin{array}{l}0,231 * 0,290 \\
(0,066)\end{array}$ & 0,297 \\
\hline 5 & $\operatorname{Sikap}\left(\mathrm{Y}_{1}\right) \rightarrow$ Minat $\left(\mathrm{Y}_{2}\right)$ & $0,043 \mathrm{~s}$ & - & 0,043 \\
\hline
\end{tabular}

Sumber: Data Penelitian, 2019

Pada Tabel 3, efek mediasi variabel sikap $\left(\mathrm{Y}_{1}\right)$ pada pengaruh tak langsung persepsi manfaat $\left(\mathrm{X}_{1}\right)$ terhadap minat $\left(\mathrm{Y}_{2}\right)$ lebih besar dari pengaruh tak langsung persepsi manfaat $\left(\mathrm{X}_{1}\right)$ terhadap minat $\left(\mathrm{Y}_{2}\right)$ yaitu dengan koefisien jalur sebesar 0,744 . Temuan ini memberikan petunjuk bahwa persepsi manffat memiliki pengaruh yang lebih besar jika dibandingkan dengan variabel kemudahaan penggunaan, sehingga dapat dikatakan bahwa semakin bermanfaatnya internet banking bagi pengguna maka dapat mempengaruhi sikap pengguna menjadi positif dan berdampak pada minat dalam menggunkan internet banking. Dimana semakin bermanfaatnya internet banking dan sikap pengguna semakin positif berdampak pada semakin tingginya minat menggunakan internet banking pada PT Bank Rakyat Indonesia Cabang Denpasar Renon. Hal ini berarti bahwa jika persepsi manfaat yang dicerminkan dari indikator adanya penggunaan sistem mampu meningkatkan kinerja individu (improves job performance), penggunaan sistem mampu menambah tingkat produktifitas individu (increases productivity), penggunaan sistem mampu meningkatkan efektifitas kinerja individu (enhances effectiveness) dan penggunaan sistem bermanfaat bagi individu (the system is useful) berdampak pada sikap yang terlihat dari indikator komponen kognitif, komponen afektif dan komponen konatif maka akan berdampak pada meningkatnya minat yang dapat dilihat dari indikator minat refrensial, minat exploratif, minat transaksional dan minat preferensial. 
Dimana semakin mudah cara menggunakan internet banking dan sikap pengguna semakin positif berdampak pada semakin tingginya minat menggunakan internet banking pada PT Bank Rakyat Indonesia Cabang Denpasar Renon. Hal ini berarti bahwa jika kemudahaan yang dicerminkan dari indikator interaksi individu dengan sistem jelas dan mudah dimengerti (clear and understandable), tidak dibutuhkan banyak usaha untuk berinteraksi dengan sistem tersebut (does not require a lot of mental effort), sistem mudah digunakan (easy to use) dan mudah mengoperasikan sistem sesuai dengan apa yang ingin individu kerjakan (easy to get the system to do what he/she wants to do) berdampak pada sikap yang terlihat dari indikator komponen kognitif, komponen afektif dan komponen konatif maka akan berdampak pada meningkatnya minat yang dapat dilihat dari indikator minat refrensial, minat exploratif, minat transaksional dan minat preferensial.

Hasil pengujian hipotesis menunjukkan bahwa persepsi manfaat berpengaruh positif dan signifikan terhadap sikap. Hasil ini memberi makna bahwa semakin bermanfaatnya internet banking mampu meningkatkan sikap pengguna internet banking. Temuan penelitian ini memberikan gambaran bahwa persepsi manfaat yang cenderung mengedepankan penggunaan sistem mampu meningkatkan kinerja individu (improves job performance), penggunaan sistem mampu menambah tingkat produktifitas individu (increases productivity), penggunaan sistem mampu meningkatkan efektifitas kinerja individu (enhances effectiveness) dan penggunaan sistem bermanfaat bagi individu (the system is useful) dapat meningkatkan sikap yang tercermin dari komponen kognitif, komponen afektif dan komponen konatif. Persepsi manfaat dan sikap merupakan faktor yang sangat penting dimana manajemen harus bisa memberikan persepsi manfaat yang baik kepada pengguna internet banking agar sikap pengguna semakin positif dan perusahaan harus bisa membangkitkan sikap positif pengguna internet banking agar pengguna internet banking semakin meningkat.

Hasil penelitian ini mendukung hasil penelitian yang dikemukan Istiarni (2014) mengemukakan bahwa persepsi manfaat berperan penting dalam mempengaruhi sikap, bahwa dapat diketahui bila layanan uang elektronik memberikan berbagai manfaat bagi penggunanya, maka pengguna dengan senang hati akan menggunakan layanan uang elektronik. Hal tersebut nantinya secara langsung akan mempengaruhi sikap dalam menggunakan layanan uang elektronik dan persepsi manfaat berpengaruh positif dan signifikan terhadap sikap.

Berdasarkan hasil penelitian yang dilakukan Novita \& Giantari (2016) mengemukakan bahwa sikap pemakaian internet banking yang secara terusmenerus dan berkala dapat menumbuhkan hubungan jangka panjang antara nasabah dengan pihak bank. Oleh sebab itu untuk mempertahankan hubungan jangka panjang dengan nasabahnya, bank harus selalu berkomunikasi dengan nasabahnya agar sikap nasabah menjadi semakin meningkat dan persepsi manfaat berpengaruh positif dan signifikan terhadap sikap.

Hasil pengujian hipotesis menunjukkan bahwa kemudahan pengguna berpengaruh positif dan signifikan terhadap sikap. Hasil ini memberi makna bahwa semakin mudah cara menggunakan internet banking maka mampu meningkatkan sikap pengguna internet banking. Temuan penelitian ini 
memberikan gambaran bahwa kemudahan pengguna yang cenderung mengedepankan interaksi individu dengan sistem jelas dan mudah dimengerti (clear and understandable), tidak dibutuhkan banyak usaha untuk berinteraksi dengan sistem tersebut (does not require a lot of mental effort), sistem mudah digunakan (easy to use) dan mudah mengoperasikan sistem sesuai dengan apa yang ingin individu kerjakan (easy to get the system to do what he/she wants to do) dapat meningkatkan sikap yang tercermin dari komponen kognitif, komponen afektif dan komponen konatif. Kemudahan penggunaan dan sikap merupakan faktor yang sangat penting dimana manajemen harus bisa memberikan kemudahan penggunaan yang baik kepada pengguna internet banking agar sikap pengguna semakin positif dan perusahaan harus bisa membangkitkan sikap positif pengguna internet banking agar pengguna internet banking semakin meningkat.

Hasil penelitian ini mendukung hasil penelitian yang dikemukan Andriyanto (2016) mengemukakan bahwa kemudahan penggunaan dapat menimbulkan sikap yang positif dimana layanan kemudahan kegunaan internet banking memberikan berbagai manfaat bagi penggunanya, maka pengguna dengan senang hati akan menggunakan layanan tersebut dan kemudahan penggunaan berpengaruh positif dan signifikan terhadap sikap.

Berdasarkan hasil penelitian yang dilakukan Risdiyanto (2013) mengemukakan bahwa sikap konsumen terhadap belanja online tergantung dari fitur-fitur yang relevan yang terdapat dalam belanja online. Fitur belanja online dapat berupa persepsi fungsional konsumen dan dimensi utilitarian, seperti kemudahan penggunaan dan kegunaan atau persepsi emosional konsumen dan kemudahan penggunaan berpengaruh positif dan signifikan terhadap sikap.

Hasil pengujian hipotesis menunjukkan bahwa persepsi manfaat berpengaruh positif dan signifikan terhadap minat. Hasil ini memberi makna bahwa semakin bermanfaatnya internet banking mampu meningkatkan minat pengguna internet banking. Temuan penelitian ini memberikan gambaran bahwa persepsi manfaat yang cenderung mengedepankan penggunaan sistem mampu meningkatkan kinerja individu (improves job performance), penggunaan sistem mampu menambah tingkat produktifitas individu (increases productivity), penggunaan sistem mampu meningkatkan efektifitas kinerja individu (enhances effectiveness) dan penggunaan sistem bermanfaat bagi individu (the system is useful) dapat meningkatkan minat yang tercermin dari minat refrensial, minat exploratif, minat transaksional dan minat preferensial. Persepsi manfaat dan minat merupakan faktor yang sangat penting dimana manajemen harus bisa memberikan persepsi manfaat yang baik kepada pengguna internet banking agar minat pengguna semakin meningkat.

Hasil penelitian ini mendukung hasil penelitian yang dikemukan Ricmala (2016) mengemukakan bahwa minat konsumen dalam menggunakan internet banking kemungkinan adanya manfaat yang optimal yang akan diperoleh nasabah setelah menggunakan layanan internet banking tersebut, dan bisa saja dikarenakan faktor keamanan transaksi internet banking yang menyebabkan nasabah menjadi berniat dalam menggunakan layanan internet banking dan persepsi manfaat berpengaruh positif dan signifikan terhadap minat. 
Berdasarkan hasil penelitian yang dilakukan Sanjaya (2015) mengemukakan bahwa persepsi manfaat mempunyai hubungan erat terhadap minat, dimana semakin baik persepsi manfaat yang dirasakan mahasiswa maka mampu meningkatkan minat mahasiswa didalam menggunkan internet banking dan persepsi manfaat berpengaruh positif dan signifikan terhadap minat.

Hasil pengujian hipotesis menunjukkan bahwa kemudahan pengguna berpengaruh positif dan signifikan terhadap minat. Hasil ini memberi makna bahwa semakin mudah cara menggunakan internet banking maka mampu meningkatkan minat pengguna internet banking. Temuan penelitian ini memberikan gambaran bahwa kemudahan pengguna yang cenderung mengedepankan interaksi individu dengan sistem jelas dan mudah dimengerti (clear and understandable), tidak dibutuhkan banyak usaha untuk berinteraksi dengan sistem tersebut (does not require a lot of mental effort), sistem mudah digunakan (easy to use) dan mudah mengoperasikan sistem sesuai dengan apa yang ingin individu kerjakan (easy to get the system to do what he/she wants to do) dapat meningkatkan minat yang tercermin dari minat refrensial, minat exploratif, minat transaksional dan minat preferensial. Persepsi manfaat dan minat merupakan faktor yang sangat penting dimana manajemen harus bisa memberikan persepsi manfaat yang baik kepada pengguna internet banking agar minat pengguna semakin meningkat. Kemudahan penggunaan dan minat merupakan faktor yang sangat penting dimana manajemen harus bisa memberikan kemudahan penggunaan yang baik kepada pengguna internet banking agar minat pengguna semakin meningkat.

Hasil penelitian ini mendukung hasil penelitian yang dikemukan Marieta (2014) mengemukakan bahwa kemudahan penggunaan dapat menimbulkan minat yang positif dimana penggunaan internet banking yang disediakan oleh bank dilakukan melalui situs bank, yang dapat diakses oleh nasabah setiap saat tanpa harus datang ke bank. Kemudahan lainnya ialah karena situs itu sama seperti situs-situs lain pada umumnya, sehingga nasabah dapat secara langsung mengakses layanan internet banking dan kemudahan penggunaan berpengaruh positif dan signifikan terhadap minat.

Berdasarkan hasil penelitian yang dilakukan Nurrahmanto (2015) mengemukakan bahwa kemudahan penggunaan menjadi pertimbangan ssebelum melakukan belanja online. Faktor penggunaan ini berkaitan dengan bagaimana operasional belanja online. Meskipun belanja online memiliki banyak manfaat, namun kerumitan dalam berinteraksi dengan medianya dalam hal ini adalah situs jual beli online. Jika situs lebih mudah digunakan dan memberikan manfaat kepada calon pembeli makan calon pembeli ajan menggunakan situs tersebut untuk belanja online dan kemudahan penggunaan berpengaruh positif dan signifikan terhadap minat.

Hasil pengujian hipotesis menunjukkan bahwa sikap berpengaruh positif dan signifikan terhadap minat. Hasil ini memberi makna bahwa semakin positif sikap responden dalam menggunakan internet banking maka mampu meningkatkan minat pengguna internet banking. Temuan penelitian ini memberikan gambaran bahwa sikap yang cenderung mengedepankan komponen kognitif, komponen afektif dan komponen konatif dapat meningkatkan minat yang tercermin dari minat refrensial, minat exploratif, minat transaksional dan 
minat preferensial. Sikap dan minat merupakan faktor yang sangat penting dimana manajemen harus bisa memberikan kepercayaan kepada responden agar sikap responden menjadi positif dalam menggunakn internet banking agar minat pengguna semakin meningkat. Kemudahan penggunaan dan minat merupakan faktor yang sangat penting dimana manajemen harus bisa memberikan kemudahan penggunaan yang baik kepada pengguna internet banking agar minat pengguna semakin meningkat.

Hasil penelitian ini mendukung hasil penelitian yang dikemukan Nurrahmanto (2015) mengemukakan bahwa kemudahan penggunaan menjadi pertimbangan ssebelum melakukan belanja online. Faktor penggunaan ini berkaitan dengan bagaimana operasional belanja online. Meskipun belanja online memiliki banyak manfaat, namun kerumitan dalam berinteraksi dengan medianya dalam hal ini adalah situs jual beli online. Jika situs lebih mudah digunakan dan memberikan manfaat kepada calon pembeli makan calon pembeli ajan menggunakan situs tersebut untuk belanja online dan kemudahan penggunaan berpengaruh positif dan signifikan terhadap minat.

Hasil pengujian hipotesis menunjukkan bahwa persepsi manfaat berpengaruh positif dan signifikan terhadap minat melalui sikap sebagai variabel mediasi. Hasil ini memberi makna bahwa semakin bermanfaatnya internet banking bagi pengguna mampu meningkatkan sikap pengguna dan berdampak pada minat pengguna internet banking semakin meningkat. Temuan penelitian ini memberikan gambaran bahwa persepsi manfaat yang cenderung mengedepankan penggunaan sistem mampu meningkatkan kinerja individu (improves job performance), penggunaan sistem mampu menambah tingkat produktifitas individu (increases productivity), penggunaan sistem mampu meningkatkan efektifitas kinerja individu (enhances effectiveness) dan penggunaan sistem bermanfaat bagi individu (the system is useful) dapat meningkatkan sikap yang tercemin dari komponen kognitif, komponen afektif dan komponen konatif serta dapat meningkatkan minat yang tercermin dari minat refrensial, minat exploratif, minat transaksional dan minat preferensial. Persepsi manfaat, sikap dan minat merupakan faktor yang sangat penting dimana manajemen harus bisa memberikan persepsi manfaat yang baik kepada pengguna internet banking agar sikap pengguna semakin positif serta minat pengguna semakin meningkat.

Hasil penelitian ini mendukung hasil penelitian yang dikemukan Stiari (2014) mengemukakan bahwa sikap dalam hal ini akan mempengaruhi minat konsumen dilihat dari perilaku yang khusus dalam memanfaatkan teknologi informasi yang ditunjukkan dengan intensi perilaku dan persepsi manfaat berpengaruh positif dan signifikan terhadap minat melalui sikap sebagai variabel mediasi.

Berdasarkan hasil penelitian yang dilakukan Prabawalingga dan Yadnyana (2016) mengemukakan bahwa adanya suatu korelasi nyata secara statistik antara persepsi kemanfaatan terhadap perilaku, persepsi kemanfaatan dan penggunaan. Apabila seseorang merasa percaya bahwa sistem informasi berguna, maka dia akan menggunakan sistem informasi tersebut, jadi minat nasabah akan meningkat jika sikap nasabah positif dalam menggunakan internet banking dan persepsi manfaat berpengaruh positif dan signifikan terhadap minat melalui sikap sebagai variabel mediasi. 
Hasil pengujian hipotesis menunjukkan bahwa kemudahan penggunaan berpengaruh positif dan signifikan terhadap minat melalui sikap sebagai variabel mediasi. Hasil ini memberi makna bahwa semakin mudah cara menggunakan internet banking maka mampu meningkatkan sikap pengguna dan berdampak pada minat pengguna internet banking semakin meningkat. Temuan penelitian ini memberikan gambaran bahwa kemudahan penggunaan yang cenderung mengedepankan interaksi individu dengan sistem jelas dan mudah dimengerti (clear and understandable), tidak dibutuhkan banyak usaha untuk berinteraksi dengan sistem tersebut (does not require a lot of mental effort), sistem mudah digunakan (easy to use) dan mudah mengoperasikan sistem sesuai dengan apa yang ingin individu kerjakan (easy to get the system to do what he/she wants to do) dapat meningkatkan sikap yang tercemin dari komponen kognitif, komponen afektif dan komponen konatif serta dapat meningkatkan minat yang tercermin dari minat refrensial, minat exploratif, minat transaksional dan minat preferensial. Kemudahan penggunaan, sikap dan minat merupakan faktor yang sangat penting dimana manajemen harus bisa memberikan kemudahan penggunaan yang baik kepada pengguna internet banking agar sikap pengguna semakin positif serta minat pengguna semakin meningkat.

Hasil penelitian ini mendukung hasil penelitian yang dikemukan Chau \& Lai (2014) mengemukakan bahwa Persepsi tentang kemudahan penggunaan sebuah teknologi sebagai suatu ukuran dimana seseorang percaya bahwa, komputer dapat dengan mudah dipahami dan digunakan. Jika seseorang merasa percaya bahwa sistem tersebut berguna maka dia akan bereaksi positif terhadap sistem tersebut dan akan menggunakannya dan kemudahaan penggunaan berpengaruh positif dan signifikan terhadap minat melalui sikap sebagai variabel mediasi.

Berdasarkan hasil penelitian yang dilakukan Feronica Mayasari et al. (2013) mengemukakan bahwa nasabah yang telah merasa nyaman, percaya, mampu dan merasa puas terhadap layanan internet banking akan terus menggunakan layanan ini untuk mendukung kegiatan mereka sehari-hari. Layanan internet banking yang baik dan canggih juga akan memberikan dampak positif terhadap bank, yaitu dengan timbulnya citra baik dari nasabah untuk bank. Sehingga mereka akan berbondong-bondong memilih bank tersebut untuk mempercayakan segala hal menyangkut keuangannya dan kemudahan penggunaan berpengaruh positif dan signifikan terhadap minat melalui sikap sebagai variabel mediasi.

\section{SIMPULAN}

Hasil penelitian ini telah menunjukkan bahwa persepsi manfaat dan kemudahan pengguna berpengaruh positif dan signifikan terhadap sikap dan minat dan juga sikap berpengaruh positif dan signifikan terhadap minat. Berdasarkan temuan tersebut, maka hasil penelitian ini mampu memperkaya pengembangan ilmu akutansi khususnya terkait perilaku konsumen dan komunikasi serta mendukung studi-studi empiris lainnya terkait dengan pengaruh persepsi manfaat dan kemudahan penggunaan terhadap minat menggunakan internet banking pada PT Bank Rakyat Indonesia Cabang Denpasar Renon dengan sikap sebagai variabel intervening. 
Berdasarkan hasil penelitian tersebut, terdapat tiga implikasi praktis yang dihasilkan. Pertama, persepsi manfaat memiliki pengaruh yang paling besar dalam menentukan sikap menggunakan internet banking dibandingkan dengan kemudahan pengguna. Hal ini menjelaskan bahwa pengguna lebih mengutamakan persepsi manfaat didalam menggunakan internet banking Bank BRI. Dimana konsumen mengharapkan internet banking harus bermanfaat didalam kegiatan konsumen. Lebih lanjut, evaluasi kemudahan pengguna pun perlu diperhatikan secara konsisten agar konsumen merasa nyaman menggunakan internet banking Bank BRI.

Kedua, berdasarkan hasil penelitian juga dapat dilihat bahwa pengaruh dari perspesi manfaat memiliki pengaruh paling besar terhadap minat menggunakan internet banking, sehingga ini dapat diinterpretasikan bahwa pengguna internet banking tidak langsung mengadopsi kemudahan pengguna yang didapatkan, melainkan mereka akan menganalisis terlebih dahulu dan mengklarifikasi apakah internet banking benar-benar bermanfaat bagi konsumen. Hal inilah yang perlu digarisbawahi oleh pihak manajemen, dimana pihak manajemen dapat memberikan berbagai informasi yang dapat dipercaya dan dapat dipertanggungjawabkan khususnya terkait tentang internet banking, misalnya pada aplikasi internet banking. Lebih lanjut, evaluasi peran kemudahan pengguna pun perlu diperhatikan secara konsisten agar pihak manajemen mengetahui lebih mendalam kebutuhan dan keinginan pengguna yang tercermin dari komentar yang telah mereka tulis.

Terakhir, dalam variabel sikap juga ditemukan memiliki nilai pengaruh yang positif dan signifikan terhadap minat menggunakan. Hal ini dapat dikaji kembali oleh pihak manajemen untuk secara konsisten menyediakan informasi yang berkualitas baik. Hal ini tentu akan berkaitan dengan sikap pengguna internet banking yang lebih dahulu mempertimbangkan informasi yang telah ada sebelum akhirnya mereka menggunakan internet banking.

\section{REFERENSI}

Istiarni, Panggih Rizki Dwi. (2014). Analisis Pengaruh Persepsi Manfaat, Kemudahan Penggunaan dan Kredibilitas terhadap Minat Penggunaan Berulang Internet Banking dengan Sikap Penggunaan Sebagai Variabel Intervening (Studi Empiris: Nasabah Layanan Internet Banking di Indonesia). Skripsi. Semarang: Universitas Diponegoro.

Mukherjee, A., dan Nath, P. (2013). A Model of Trust in Online Relationship Banking. International Journal of Bank Marketing, Vol. 21, No. 1, Pp. 5-15.

Nitisusastro, Mulyadi. (2014). Perilaku Konsumen Dalam Perspektif Kewirausahaan. Bandung: Alfabeta.

Singgih Priambodo dan Bulan Prabawani. (2015). Pengaruh persepsi manfaat, persepsi kemudahan penggunan, dan persepsi risiko terhadap minat menggunakan layanan uang elektronik (Studi Kasus pada Masyarakat di Kota Semarang). Jurnal Administrasi Bisnis, Vol.7, No. 1.

Sri Maharsi. (2017). Pengaruh Perkembangan Teknologi Informasi Terhadap Bidang Akuntansi Manajemen. Jurnal Akuntansi \& Keuangan Vol. 2, No. 2, Nopember 2017: 127 - 137. 
Tampubolon, Manahan P., (2014). Manajemen Operasi, Edisi 1, Galia Indonesia, Jakarta.

V. Venkatesh and F. D. Davis (2013), A Theoretical Extension of the Technology Acceptance Model : Four Longitudinal Field Studies," Jurnal Managemen. 